JURNAL MAUIZOH

Vol. 5, No. 1, Juli 2021, hlm. 15-26

E-ISSN 2614-4468

\title{
Strategi Komunitas Pejuang Subuh dalam Berdakwah dan menjaga Eksistensinya di Kota Jambi
}

\author{
M.Ridho, Zurqarnin, Ahdiyat Mahendra \\ UIN Sultan Thaha Saifuddin Jambi \\ Email: M.ridho.an17@gmail.com
}

\begin{abstract}
Abstrak: Penelitian ini dilatarbelakangi oleh pesatnya perkembangan komunitas pejuang subuh sehingga telah menjamur hampir di seluruh wilayah Indonesia dan telah memiliki puluhan ribu anggota, termasuk Jambi, selama 2 tahun lebih komunitas pejuang subuh Jambi telah memiliki ribuan anggota, tentunya itu semua tidak terjadi begitu saja, itu semua terjadi karena ada sebuah strategi yang dirancang baik itu strategi dalam berdakwah maupun strategi dalam menjaga eksistensinya.penelitian ini bertujuan mengetahui strategi komunitas pejuang subuh Jambi dalam berdakwah dan menjaga eksistensinya di Kota Jambi, dan efektivitas strategi yang digunakan oleh pengurus para pengurus. Penelitian yang penulis gunakan adalah penelitian kualitatif. Adapun Teknik pengumpulan data yaitu wawancara dengan 13 informan, observasi dari november 2020 hingga febuari 2021, dan dokumentasi. Hasil penelitian strategi dalam berdakwah yaitu: bersilahturahmi dengan pengurus masjid yang ada di Kota Jambi, membuat kegiatan yang menyenangkan, menciptakan hubungan yang baik kepada setiap anggota serta mengunakan media sosial dan media lainya sebagai sarana pengembangan dakwah. Strategi dalam menjaga eksistensi komunitas pejuang subuh yaitu: membuat program prioritas dan non prioritas, berkerjasama dengan berbagai komunitas dan organisasi, para da'i, serta majelis taklim yang ada di Kota Jambi, mencari dan menjaga kepercayaan donatur.
\end{abstract}

Kata-kata kunci: strategi dakwah, Komunitas Pejuang Subuh, Jambi. 


\section{A. Pendahuluan}

Islam merupakan agama dakwah yang memuat berbagai petunjuk agar manusia menjadi pribadi yang lebih baik, beradap, dan berkualitas. Islam mengajak umatnya selalu berbuat baik sehingga mampu membangun peradaban yang maju, bebas dari berbagai ancaman, penindasan, dan berbagai kekhawatiran. ${ }^{1}$ Sebagai agama dakwah, Islam yaitu agama yang menegaskan umatnya untuk menyebarluaskan dan menyiarkan Islam kepada seluruh umat manusia sebagai rahmat bagi seluruh alam. Islam sebagai agama Allah yang mengatur kehidupan didunia dan mencapai kebahagiaan hidup di akhirat.

Dakwah sesungguhnya merupakan suatu gejala kongkrit dan ada ditengahtengah masyarakat dalam penyampaian amal ma'ruf nahi mungkar dari dai (penyampai dakwah) kepada mad'u (penerima dakwah), melalui suatu saluran yang disebut media, dan menggunakan berbagai macam metode. ${ }^{2}$

Perkembangan dakwah pada organisasi masyarat (ormas) atau kelompok Islam sendiri dan bergerak dalam dakwah saja, namun berhubungan dan ketergantungan antara satu tujuan dengan tujuan dan target lain bisa di lakukan berbarengan dengan dakwah. Bahkan bisa saja dakwah menjadi semacam "gizi" dalam gerakam sosial yang menjiwainya. Polarisasi dakwah demikian, tentu saja sangat mempengaruhi bentuk dan suatu gerakan dakwah. Gerakan dakwah yang bersifat individu misalnya sangat berbeda dengan gerakan dakwah dan bentuk kelompok dan kolektif. Warna, dinamika, dan targetnya juga akan menghasilkan bentuk yang berbeda. ${ }^{3}$

Perkembangan dakwah pada organisasi masyarat (ormas) atau kelompok Islam sendiri dan bergerak dalam dakwah saja, namun berhubungan dan

\footnotetext{
${ }^{1}$ Moh. Aziz, Ilmu Dakwah, (Jakarta: Kencana,2004), 1

2 Masduqi Affandi, Ontology Dasar-Dasar Filosofi Dakwah (Surabaya: Diantama,2007) ,2

${ }^{3}$ Acap Aripudin,Perbandingan Dakwah (Bandung: Rem,Aja Posdakarya, 2014) ,12
} 
ketergantungan antara satu tujuan dengan tujuan dan target lain bisa di lakukan berbarengan dengan dakwah. Bahkan bisa saja dakwah menjadi semacam "gizi" dalam gerakam sosial yang menjiwainya. Polarisasi dakwah demikian, tentu saja sangat mempengaruhi bentuk dan suatu gerakan dakwah. Gerakan dakwah yang bersifat individu misalnya sangat berbeda dengan gerakan dakwah dan bentuk kelompok dan kolektif. Warna, dinamika, dan targetnya juga akan menghasilkan bentuk yang berbeda. ${ }^{4}$

Sayyid Muhammad Wakil mendefinisikan bahwa dakwah Islam adalah menghimpun manusia kearah kebaikan dan menuntun mereka menuju kebenaran dengan menyuruh mereka untuk berbuat baik dan melarang mereka dari perbuatan munkar. ${ }^{5}$ Banyak individu muslim, organisasi maupun kelompok yang melakukan aktivitas dakwah. Namun demikian, pelaksanaan dakwah tersebut dilakukan oleh umat Islam dalam beragam cara dan bentuk berdasarkan pada pijakan, pemahamaan, dan interprestasi tentang Islam. Indivividu maupun kelompok dakwah. ${ }^{6}$

Dalam konteks dakwah kelompok, komunitas pejuang subuh merupakan komunitas telah lama bergerak dalam dunia dakwah, lahir pada tahun 2012 berawal dari keprihatinan pada kondisi masjid yang hanya ramai oleh kakek-kakek dan bapak bapak saja ketika waktu shalat subuh, akhirnya mendorong sekelompok pemuda membuat komunitas pejuang subuh komunitas yang mengajak para generasi muda agar mau datang ke masjid untuk salat subuh

Awal mula terbentuknya komunitas pejuang subuh pada tahun 2012, tepatnya dibulan ramadhan. Sebuah gerakan yang mengajakan kepada orang-orang, terutama kepada pemuda untuk melaksanakan sholat shubuh berjamaah di masjid. Melihat banyak program-program yang dibuat tidak lain sebagai strategi untuk perkembangan

\footnotetext{
${ }^{4}$ Acap Aripudin,Perbandingan Dakwah (Bandung: Rem,Aja Posdakarya, 2014) ,12

${ }^{5}$ Sayyid Muhammad Nuh, Mari Berdakwah (Yogyakarta : Bina Media, 2005),32.

${ }^{6}$ Acap Aripudin, Perbandingan, 33.
} 
dakwah komunitas pejuang subuh itu sendiri dan sebagai tujuan utama diterimanya dakwah komunitas pejuang subuh Jambi oleh masyarakat anak-anak muda yang ada di Kota Jambi.

Dengan ada hal ini membuat penulis tertarik untuk meneliti bagaimana strategi yang dilakukan komunitas pejuang subuh dalam berdakwah karena sama kita ketahui komunitas ini merupakan komunitas yang berfokus berdakwah atau mengajak masyarakat untuk bisa melaksanakan kewajibanya sebagai seorang muslim yaitu untuk melaksanakan sholat secara tepat waktu terutama pada sholat subuh selain adanya strategi komunitas pejuang subuh dalam berdakwah peneliti juga melihat adanya upaya atau strategi yang dilakukan pengurus komunitas pejuang subuh Jambi dalam untuk menjaga eksistensinya dalam pandangan masayarakat kota Jambi seperti banyak berkerjasama dengan komunitas dan organisasi yang ada di Kota Jambi dan lainya agar komunitas bisa semakin eksis dan memberikan kontibusi positif dalam berkehidupan bermasyarakat.

Seiring berjalanya waktu, gerakan ini pun berkembang menjadi komunitas Islam yang bernama pejuang subuh, dan saat ini pejuang subuh telah tersebar di kota diseluruh Indonesia diantaranya ialah Jakarta, Bandung, Medan dan daerah lainya. Jumlah anggota pejuang subuh kini telah mencapai ribuan bahkan puluhan ribu orang di seluruh Indonesia. Tak terkecuali di Jambi komunitas pejuang subuh juga berkembang dengan pesat di salah satu Provinsi di pulau Sumatera ini, tercatat baru 2 tahun lebih berjalanya komunitas pejuang subuh Jambi sudah mempunyai seribu anggota, hal ini tentu tidak serta merta terjadi begitu saja, tentu adanya strategi dalam pelaksanaan dakwah pejuang subuh sehingga menjadi suatu gerakan yang sudah memiliki puluhan ribu anggota diseluruh Indonesia dan di kota jambi sendiri memiliki seribu anggota yang dapat dilihat melalui media sosial whatsApp komunitas pejuang subuh Jambi walaupun banyak diantara anggota masih fasiv atau tidak aktif secara keseluruhan anggota. 
Berdasarkan pengamatan sementara penulis, pada proses perkembangan dakwah komunitas pejuang subuh Jambi banyak mengunakan strategi-strategi agar dakwah komunitas pejuang subuh Jambi diterima oleh masyarakat di Kota Jambi terutama dari kalangan anak muda Kota Jambi. Saat melakukan pengamatan penulis menemukan strategi komunitas pejuang subuh Jambi yang dilakukan oleh pengurus komunitas, para pengurus lebih sering melakukan diskusi dan sharing-sharing santai dengan anggota maupun yang non anggota dalam obrolan tersebut pengurus memasukan materi-materi akan pentingnya sholat subuh dan ganjaran bagin orang yang melaksanakan secara Istiqomah. Selain itu penulis melihat banyak programprogram yang dibuat tidak lain sebagai strategi untuk perkembangan dakwah komunitas pejuang subuh itu sendiri dan sebagai tujuan utama diterimanya dakwah komunitas pejuang subuh Jambi oleh masyarakat anak-anak muda yang ada di Kota Jambi.

Dengan ada hal ini membuat penulis tertarik untuk meneliti bagaimana strategi yang dilakukan komunitas pejuang subuh dalam berdakwah karena sama kita ketahui komunitas ini merupakan komunitas yang berfokus berdakwah atau mengajak masyarakat untuk bisa melaksanakan kewajibanya sebagai seorang muslim yaitu untuk melaksanakan sholat secara tepat waktu terutama pada sholat subuh selain adanya strategi komunitas pejuang subuh dalam berdakwah peneliti juga melihat adanya upaya atau strategi yang dilakukan pengurus komunitas pejuang subuh Jambi dalam untuk menjaga eksistensinya dalam pandangan masayarakat kota Jambi seperti banyak berkerjasama dengan komunitas dan organisasi yang ada di Kota Jambi dan lainya agar komunitas bisa semakin eksis dan memberikan kontibusi positif dalam berkehidupan bermasyarakat.

Untuk mengetahui lebih lanjut mengenai aktifitas serta strategi komunitas pejuang subuh dalam berdakwah dan upaya menjaga eksistensinya di Kota Jambi dan bagaimana efektivitas strategi yang dilakukan pengurus pejuang subuh Jambi 
tersebut, maka penulis tertarik untuk melakukan sebuah penelitian lebih mendalam dengan mengangkat judul "Efektivitas Strategi Komunitas Pejuang Subuh dalam Berdakwah dan Menjaga Eksistensinya di Kota Jambi.

Pendekatan penelitian yang digunakan adalah pendekatan penelitian kualitatif deskriptif. dalam ilmu komunikasi, pendekatan penelitian kualitatif deskriptif yaitu penelitian yang bertujuan untuk mengangkat fakta, keadaan, variabel, dan fenomena-fenomena yang terjadi ketika penelitian berlangsung dan menyajikan apa adanya.

\section{B. Strategi Komunitas Pejuang Subuh dalam Berdakwah di Kota Jambi}

Pengerak komunitas pejuang subuh melalukan berbagai macam upaya dalam berdakwah di Kota Jambi, mengunakan strategi yang tepat merupakan kunci utama agar proses dakwah terus berkembang dan komunitas pejuang subuh semakin diterima dan diakui sebagai komunitas membawa dampak positif atas keberadaanya di Kota Jambi. Strategi yang dilakukan anggota remaja masjid dalam merekrut anggota remaja masjid yakni dengan cara.

Bersilaturahmi merupakan hal yang amat penting yang dilakukan oleh pengurus komunitas pejuang subuh pada awal berkembanganya dakwah yang dilakukan komunitas untuk mengajak masyarakat kembali memakmurkan masjid dengan sholat berjamaah, bersilaturahmi yang penulis maksud ialah dengan masyarakat dan pengurus beberapa masjid di kota Jambi, dalam silaturahmi ini pengurus komunitas pejuang subuh menyampaikan maksud berdirinya komunitas pejuang subuh agar gerakan ini mendapatkan suport dari pengurus masjid dan tokoh masyarakat. 


\section{Berdakwah menggunakan Media Sosial}

Media sosial yang digunakan komunitas pejuang Jambi subuh dalam berdakwah diantaranya adalah:

Facebook

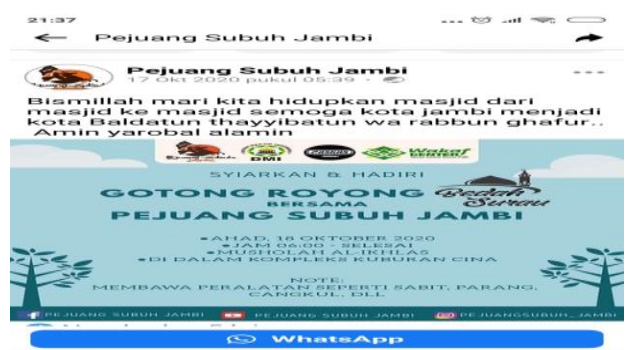

Postingan Facebook Pejuang Subuh Jambi

Instagram

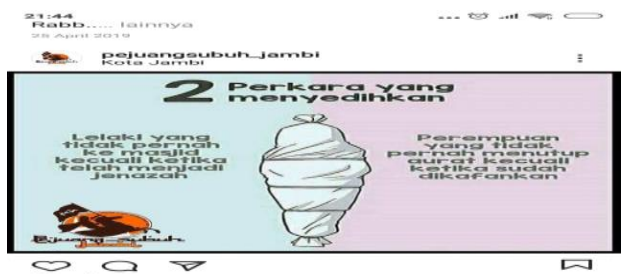

SE Bukn

क $क$ क

Postingan Instagram Pejuang Subuh Jambi

WhatsApp

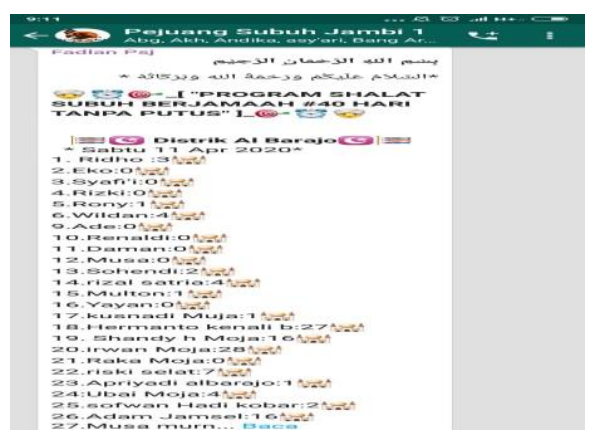

Photo Group WhatsApp Pejuang Subuh Jambi 
Youtube

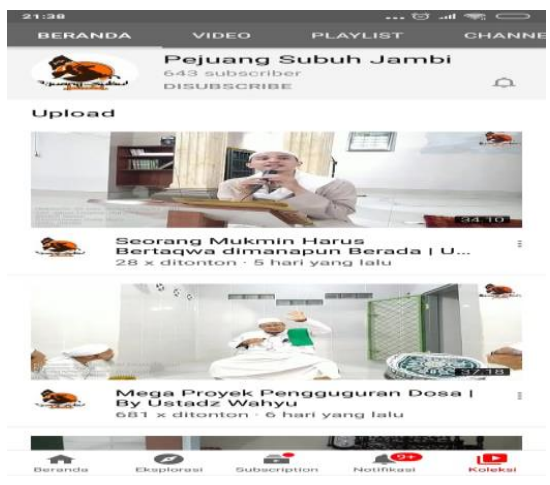

Youtube Pejuang Subuh Jambi

\section{Membangun Komunikasi}

Membangun Komunikasi yang baik merupakan hal amat penting untuk membangun hubungan dengan orang lain terutama ketika mempunyai maksud antar sesama. Karena dengan berkomunikasi yang baik dapat membuat seseorang menjadi semakin akrab. Sejak kecil kita telah diajarkan oleh orang tua kita, kita diajarkan untuk selalu berkata-kata yang baik. Selain itu dengan berkomunikasi yang baik selain membuat semakin akrab antara satu dengan yang lain. Selain itu juga dapat membuat perasaan lawan bicara semakin nyaman dan senang ketika berbicara dengan kita.

Pada mula berdirinya komunitas pejuang subuh dan sampai saat ini komunikasi yang baik merupakan salah satu strategi yang paling sering digunakan contohnya ketika pengurus komunitas pejuang subuh ketika mengajak calon anggota untuk bergabung dengan komunitas mereka, mereka memulai dengan memilih calon anggota yang mereka temui di masjid ketika sholat sebelum atau selesai sholat berjamaah, pengurus dan anggota pejuang subuh memulai pendekatan dengan calon anggota dengan komunikasi yang baik, berdiskusi dengan kalimat yang lembut dan mencoba memahami permasalahan yang calon anggota alami terutama pada hal yang berkaitan sholat subuh dan berupaya menawarkan solusi agar bisa melaksanakan 
sholat subuh secara berjamaah di masjid, selain itu komunitas pejuang subuh juga menjadi wadah bagi anggota pejuang untuk belajar berkomunikasi yang baik, mereka diajarkan bagaimana memulai komunikasi yang baik ketika mengenalkan komunitas pejuang subuh Jambi kepada masyarakat banyak.

Membuat kegiatan yang banyak disenangi kaum muda merupakan salah satu upaya dari komunitas pejuang subuh Jambi dalam berdakwah kepada anak-anak muda, sebagaimana yang kita ketahui bahwa pada mas dari masa kanak-kanak menuju masa dewasa, pada usia para pemuda atau remaja mulai mencari jati diri mereka dan mereka lebih cendrung menghabiskan waktu dengan hal-hal yang disenanginya seperti, bermain game, berolahraga, jalan jalan dan hal-hal yang menyangkan lainya, sehingga dibuatlah berbagai kegiataan yang disenangi pemuda dengan tujuan semakin banyak anggota yang bertambah dari para pemuda.

\section{B. Strategi Komunitas Pejuang Subuh di Kota Jambi}

Selain strategi dalam berdakwah, Pengurus komunitas pejuang subuh Jambi juga harus mempunyai strategi atau taktik dalam menjaga eksistensi komunitas agar apa yang direncanakan akan berjalan sesuai dengan rancana.

Sedangkan eksistensi merupakan hal yang penting bagi setiap komunitas, karena melalui eksistensi keberadaan komunitas sosial akan langgeng dan diakui keberadaanya. Antara komunitas yang satu komunitas dengan komunitas yang lain tentu saja memiliki eksisistensi yang berbeda tergantung bagaimana strategi yang mereka gunakan untuk mempertahankan eksistensinya.

Strategi yang dilakukan pengurus komunitas pejuang subuh dalam mempertahankan eksistensinya di Kota Jambi yaitu membuat program-program merupakan strategi utama dari komunitas pejuang subuh Jambi dalam menjaga eksistensinya karena program-program ini yang membuat komunitas pejuang subuh semakin berkembang dan semakin dikenal masyarakat dan para pemuda kota 
Jambi. Berkerjasama dengan berbagai komunitas, lembaga sosial atau organisasi lain merupakan strategi yang sering dilakukan pengurus komunitas pejuang subuh dalam mempertahankan eksistensinya di kota Jambi, komunitas pejuang subuh Jambi tidak hanya berkerjasama dalam kegiataan dakwah saja namun juga sering aktif dalam kegiatan sosial kemasyarakatan sehingga komunitas pejuang subuh Jambi semakin eksis dimata masyarakat berikut kegiatan komunitas pejuang subuh yang berkejasama dengan banyak pihak sebagai suatu upaya mempertahankan eksistensinya di Kota Jambi.

\section{Bekerjasama dengan Komunitas dan Lembaga yang Bergerak dalam Kegiatan Sosial}

Dalam kegiataan Sosial komunitas pejuang berkerjasama dengan komunitas infaq beras Jambi, dimana komunitas infaq beras ini ialah komunitas yang menghimpun dana dari para donatur kemudian uang tersebut dibelajakan untuk membeli beras kemudian disalurkan ke pesantren, rumah yatim dan

Dhuafa dan rumah tahfidz, pada kegiatan sosial yang dilaksanakan komunitas infaq beras Jambi biasanya komunitas pejuang subuh Jambi ikut serta dalam proses penghimpunan dana dari orangtua asuh sampai pendistribusikan beras kepada santri yatim dan penghafal Qur'an selain pendistibusirian beras komunitas infaq beras komunitas infaq beras juga mempunyai program makan siang gratis (MSG) yang dilaksanakan pada setiap sholat jum'at selesai dilaksanakan banyak anggota dari komunitas pejuang subuh ikut membantu kegiataan tersebut sehingga hal ini membuat eksistensi komunitas pejuang subuh semakin baik dan setiap perbuatan pasti ada timbal baliknya komunitas infaq beras juga banyak mensuport kegiataan komunitas pejuang subuh salah satu yang penulis dapat penulis temui dilapangan sering kali ketua dari komunitas infaq beras jambi ikut berpastisipasi dalam kegiatan komunitas pejuang subuh Jambi.

Selain berkerjasama dengan komunitas dan lembaga yang bergerak dalam 
kegiataan sosial komunitas pejuang subuh Jambi juga berkejasama dengan komunitas yang bergerak dalam dakwah bil makruf atau komunitas yang lebih memfokuskan kegiataan kegiantanya pada jalan mengajak orang dalam berbuat baik, dalam kegiataan dakwah makruf ini banyak sekali komunitas yang berkerjasama dengan komunitas pejuang subuh diantaranya ialah komunitas youth move up, komunitas kutup, komunitas one day one juz (ODOJ), komunitas Riau-Jambi mengaji, baitul mal hidayatullah dan masih banyak lagi komunitas yang lain yang berkerjasama dengan komunitas pejuang subuh Jambi.

\section{Penutup}

Berdasarkan uraian dan pembahasan diatas, berdasarkan hasil penelitian lapangan, wawancara dan dokumentasi yang dipadukan dan didukung dengan teori dan buku penunjang dapat penulis simpulkan bahwa.

Strategi komunitas pejuang subuh Jambi dalam berdakwah di Kota Jambi yang pertama dilakukan saat komunitas baru dibentuk pengurus komunitas pejuang subuh Jambi bersilahturahmi dengan pengurus masjid dengan meminta dukungan terhadap kegiatan komunitas kemudian memanfaatkan pengkembangan zaman dengan menggunakan media sosial karena sebagian besar orang menggunakanya terutama para pemuda, selain itu pengurus komunitas pejuang subuh Jambi membangun komunikasi yang baik antara satu anggota dengan anggota yang lain dengan cara berdiskusi serta makan bersama kemudian pengurus komunitas pejuang subuh Jambi juga membuat kegiatan-kegiatan yang menarik pemuda sehingga semakin banyak yang bergabung dengan komunitas lebih-lebih dari kalangan pemuda dan yang terakhir menggunakan media lainya spanduk-spanduk yang mengandung pesan dakwah.

Adapun strategi komunitas pejuang subuh Jambi dalam menjaga eksisitensinya di Kota Jambi ialah membuat dan menentukan program-program 
prioritas dan non prioritas kemudian berupaya kemudian berupaya melaksanakan program-program tersebut semaksimal mungkin, berkerjasama dengan komunitas organisasi dan lembaga yang bergerak dalam sosial kemasyarakatan, dalam dakwah bil makruf dan dengan organisasi masyarakat yang bergerak dalam dakwah nahi mungkar, berkerjasama dengan dengan para da'i dan majelis taklim yang ada di Kota Jambi, membuat striker dan seragam komunitas, mencari dan menjaga kepercayaan para donatur, membuat dan memperbanyak spanduk promosi pesan dakwah.

\section{Daftar Pustaka}

Affandi, Masduq Ontology Dasar-Dasar Filosofi Dakwah Surabaya: Diantama,2007 Aripudin, Acap,Perbandingan Dakwah Bandung: Remaja Posdakarya, 2014

Aripudin, Acap ,Perbandingan Dakwah Bandung: Remaja Posdakarya, 2014

Aziz, Moh Ilmu Dakwah, Jakarta: Kencana,2004

Djunaidi Ghony, Fauzan Almanshur, Metode Penelitian Kualitatif, Yogyakarta: AR-Ruzz Media, 2017

Fitrah, Luthfiyah, Metodologi Penelitian Kualitatif Tindakan Kelas dan Studi Kasus, Jawa Barat: Jejak, 2017

Lexy J. Moleong, Metodologi Penelitian Kualitatif, (Bandung: Remaja Rosdakarya, 2004

Suryani Hendryadi, Metode Riset Kualitatif Teori dan Aplikasi Pada Penelitian Bidang Mnajemen dan Ekonomi Islam, Jakarta: Faja Intterpratama Mandiri, 2015

Nuh, Muhammad Sayyid Mari Berdakwah Yogyakarta: Bina Media, 2005

Untoro, Joko Buku pintar Pelajaran SMA/MA IPS Jakarta: Wahyu Media, 2010 